Sustinere

Journal of Environment and Sustainability

Volume 1 Issue 1 (2017) 1 - 9

Print ISSN: 2549-1245 Online ISSN: 2549-1253

Website: https://sustinerejes.com E-mail: sustinere.jes@iain-surakarta.ac.id

\title{
RESEARCH PAPER \\ Isolation and characterization of Lignocelullolitic microbes from oil palm empty fruit bunches (EFB)
}

\author{
Ariana $1^{*}{ }^{*}$, Krishna P. Candra ${ }^{2}$ \\ ${ }^{1}$ Institut Agama Islam Negeri (IAIN) Surakarta, Sukoharjo, Indonesia \\ ${ }^{2}$ Universitas Mulawarman, Samarinda, Indonesia \\ Article history: \\ Received 01 December 2016 | Accepted 01 February 2017 | Available online 01 June 2017
}

\begin{abstract}
Oil palm empty fruit bunches (EFB) is one of the major by-products of palm oil production. This lignocellulosic biomass is commonly used as a fertilizer at oil palm plantations. Unfortunately, the composting process of EFB is very slow. This study aimed to identify potential lignocellulosic microbes isolated from EFB. This information is essential for improving EFB biodegradation process by reducing the decomposition time. Samples of approximately 6, 12, and 24-month-old EFB were obtained from two palm oil mills in East Kalimantan, Indonesia. The isolation of lignocellulytic microbes utilized selective medium cellulose congo red agar (CCRA) while its characterization used lignin agar $(\operatorname{LgA})$ and oil palm empty fruit bunches agar (EFBCRA). As much as 430 isolates were successfully collected and 12 of them exhibited promising capability to synthesize lignocellulolytic enzyme, the key for FEB degradation.
\end{abstract}

Keywords: Lignocellulose; lignocellulases; microbe characterization; oil palm empty fruit bunches (EFB)

\section{Introduction}

Palm oil production process generates approximately $45 \%$ of solid waste consist of manure, dust, fiber, fruit shell, and oil palm empty fruit bunches (EFB). EFB constitutes nearly $50 \%$ of those solid wastes. This lignocellulosic biomass, composed of cellulose, hemicellulose, lignin and other extractive materials, has great potential to be processed as bioenergy, fertilizer and other products with higher economic value. Because of the high content of lignin of up to $21 \%$, EFB carries similar hardness as wood (Kumar et al., 2009). EFB also contains energy of $18795 \mathrm{~kJ} \mathrm{~kg}^{-1}$, makes it one of the choices for a source of renewable energy (Prihandana \& Hendroko, 2008). At the palm oil plantation itself, EFB is commonly applied as fertilizer; it biodegrades and becomes compost that helps to enrich the soil. 
Degradation of lignocellulosic biomass, with high lignin concentration, requires a pretreatment process that can be performed through a physical, chemical, mechanical, as well as biological method using microbes or enzymes (Atlas \& Bartha, 1986). The purpose of pretreatment is to remove or to break down lignin structure to increase the digestibility of cellulose fraction so that the decomposition process is more efficient. Natural decomposition process of lignocellulosic biomass, instead of by a certain microorganism, is performed by a consortium of many types of microorganism.

White rot fungi, for example, is the fungi that capable of degrading lignocellulosic biomass by producing extracellular enzymes that destroy cellulose and lignin. Cellulose and hemicellulose are utilized by white rot fungi for growth substrate, while lignin is degraded during nutrient (such as nitrogen, carbon, and sulphur) deficiency conditions (Hatakka, 2005). Other examples are Phanerochaeta porigens and Phanerochaeta chrysosporium (Goenadi \& Away, 1993; Hatakka, 2005). Additionally, Trichoderma spp, Fusarium oxysporum, Aspergillus niger, Penicillium citrinum, Rhizopus oryzae, Aspergillus nidulans are known as types of fungi that mostly play role in the decomposition of lignocellulosic biomass (Gunam et al., 2010; Mukhlis et al., 2013; Taherzadeh \& Karimi, 2007; Tristianti et al., 2013). From bacterial microorganism, Bacillus circulans and Sphingomonas paucimobilis are known to be able to produce lignocellulolytic degrading enzymes (Kurakake et al., 2007) such as cellulases, hemicellulases, and lignin-degrading enzymes.

Exploration of microbial diversity can be done in-situ at the waste location and ex-situ in the laboratory. The information obtained from such exploration is essential to achieve an effective EFB biodegradation (Baharuddin et al., 2009). However, little research has been done to explore the diversity of lignocellulolytic-microbial inhabiting EFB. Studies on the decomposition of EFB, especially in Indonesia, predominantly used non-indigenous microbes instead of isolates from EFB itself (Andayani, 2011). Bio-activator is commonly used in the decomposition of cellulose waste to accelerate the process (Suriadikarta et al., 2006) even though indigenous microorganism (IMO) has a higher tolerance to the environmental conditions of its original habitats (Oktavia, 2010). It has been proven that the use of IMO speeds up EFB vermicomposting process (Azizah et al., 2014). The purpose of this study was to identify potential lignocellulolytic microbes in EFB. This research will be used as basic information in developing a better EFB biodegradation process by diminishing decomposition time.

\section{Method}

\subsection{Screening of cellulolytic microbial}

EFB was derived from Longkali palm oil mills (POM) and Samuntai POM PTPN XVI Tanah Grogot, East Kalimantan, Indonesia. Samples from each location were divided into three categories based on the age of EFB, i.e. 6, 12, and 24 months old. One gram of the sample was added to $9 \mathrm{~mL} \mathrm{NaCl} 0.85 \%$ sterile and diluted up to $10^{10}$ time. The microbial screening used pour plate method. As much as $0.5 \mathrm{~mL}$ sample from each dilution were poured onto the medium of cellulose congo red agar (CCRA), modified from Kausar et al. (2012), that contained $0.5 \mathrm{~g} \mathrm{~L}^{-1} \mathrm{KH}_{2} \mathrm{PO}_{4}, 0.25 \mathrm{~g} \mathrm{~L}^{-1} \mathrm{MgSO}_{4}, 2.0 \mathrm{~g} \mathrm{~L}^{-1}$ Carboxy Methyl Cellulose (CMC), $15 \mathrm{~g} \mathrm{~L}^{-1}$ agar, $0.2 \mathrm{~g} \mathrm{~L}^{-1}$ congo red, and $2.0 \mathrm{~g} \mathrm{~L}^{-1}$ gelatin. Samples were incubated at 
room temperature for 48 hours. Cellulolytic microbial colonies were indicated by a clear zone around the colony.

\subsection{Isolation and characterization of lignocellulolytic microbes}

Colonies that have the highest cellulolytic index were subsequently regrown using CCRA. The lignocellulolytic activity of selected isolates was then characterized using lignin agar (LgA) and empty fruit bunch cellulose congo red agar (EFBCRA) in order to observe their capability to degrade lignin and natural substrate (EFB powder).

The LgA consisted of $0.5 \mathrm{~g} \mathrm{~L}^{-1} \mathrm{KH}_{2} \mathrm{PO}_{4}, 0.25 \mathrm{~g} \mathrm{~L}^{-1} \mathrm{MgSO}_{4}, 2.0 \mathrm{~g} \mathrm{~L}^{-1}$ lignin, $15 \mathrm{~g} \mathrm{~L}^{-1}$ agar, and $2.0 \mathrm{~g} \mathrm{~L}^{-1}$ gelatin; while EFBCRA contained $0.5 \mathrm{~g} \mathrm{~L}^{-1} \mathrm{KH}_{2} \mathrm{PO}_{4}, 0.25 \mathrm{~g} \mathrm{~L}^{-1} \mathrm{MgSO}_{4}, 2.0 \mathrm{~g} \mathrm{~L}^{-1}$ $\mathrm{EFB}, 15 \mathrm{~g} \mathrm{~L}^{-1}$ agar, $0.2 \mathrm{~g}$ congo red, and $2.0 \mathrm{~g} \mathrm{~L}^{-1}$ gelatin. Cellulolytic index, lignin index, and lignocellulolytic index are the ratio between diameters of the clear zone surrounding colonies with diameter of the colonies. It illustrates the capability of microbes to degrade lignocellulosic materials.

Microscopic morphology of bacteria and fungi was observed using electron microscope with 100x and 400x magnification. For bacteria, the colonies were subjected to gram-negative staining procedure prior to microscope observation.

\section{Result and Discussion}

\subsection{Screening of cellulolytic microbial}

This study successfully isolated 430 microbes from Longkali POM and Samuntai POM. The isolation to obtain cellulolytic microbes used selective medium CCRA. The microbes grow on this medium are only they that can use CMC, an amorphous type of cellulose substrate, as the carbon source. CMC is hydrolyzed into oligosaccharide due to the activity of endo 1.4- $\beta$-gluconate which breaks the bond of the $\beta$-1,4-glycosidic polymer of glucose (Meryandini et al., 2009). In this experiment, all isolates were capable of cellulose degradation; indicated by the presence of clear zone around the colonies. This zone evidence the capability of the respective microbe to produce cellulose enzyme (Figure 1).

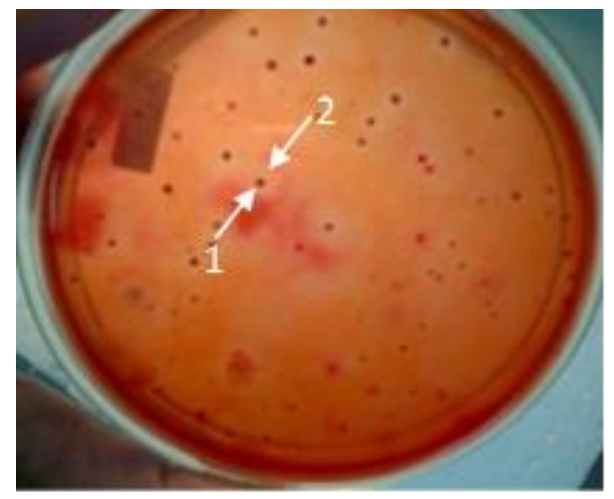

(a)

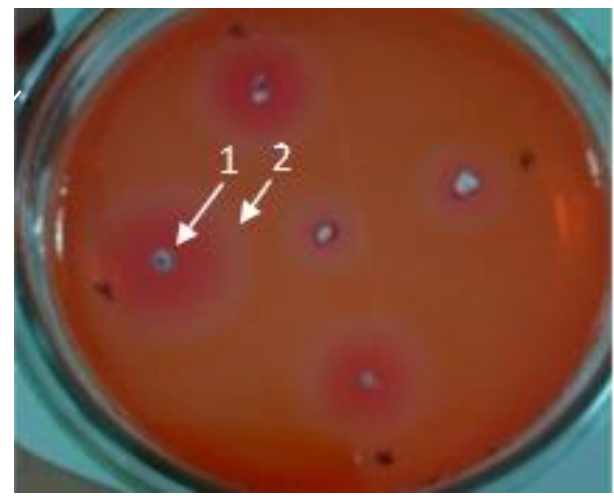

(b)

Figure 1. (a) Microbe isolation: 1 is the colony, 2 is the clear zone around microbe colony; (b) fungi isolation: 1 is the colony and the white spore, 2 is the clear zone around fungi colony (isolation condition: CCRA medium, $25^{\circ} \mathrm{C}, 48$ hours) 
The screening result showed that colonies were dominated by fungi with distinct morphological features of having (powder-like) spore that gradually amassed on the surface of the medium (Figure 1b). The observation of fungi colonies under a microscope revealed the slim and branched mycelium (Figure 2a). Previous studies reported that fungi can decompose lignocellulosic materials more quickly and intensively than bacteria. The species of fungi (white rot fungi) such as Phanerochaeta chrysosprorium, Phlebiaradiata, Tremetes versicolor, Ceriporiopsis subvermispora have the ability to degrade lignocellulosic materials (Suriadikarta et al., 2006).

Other colonies appeared to be irregularly shaped, velvety yellowish mucus (Figure 3a). After gram-staining and microscope observation, isolates were revealed to be gramnegative cocci bacteria (Figure 3b). Suriadikarta et al. (2006) reported that some types of bacteria such as Pseudomonas spp, Bacillus spp, Streptomyces spp, Flavobacterium spp, Clostridium spp, spp Thermonospora capable of lignocellulosic materials decomposition, even though not as fast as fungi.

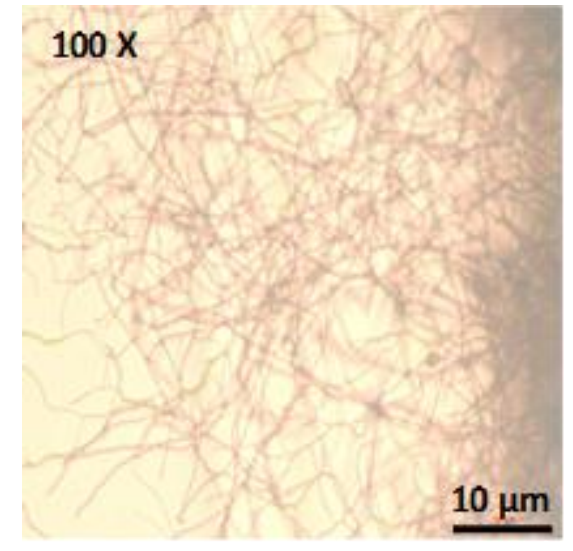

(a)

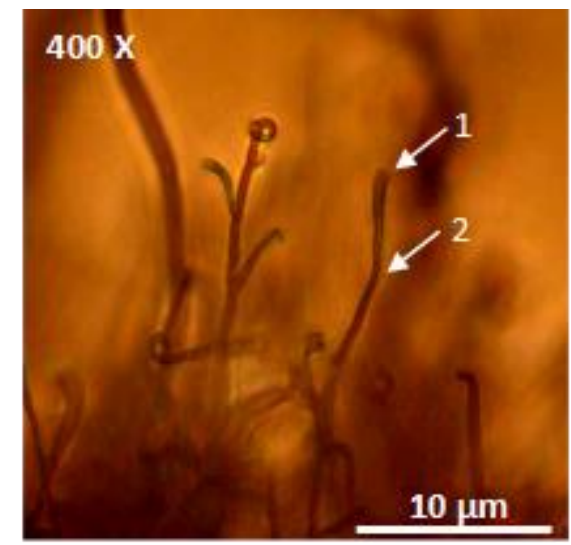

(b)

Figure 2. Microscopic morphology of fungi: (a) 100x magnification shows branched mycelium; (b) 400x magnification shows reproductive organs, 1 is sporangium and 2 is sporangiophore

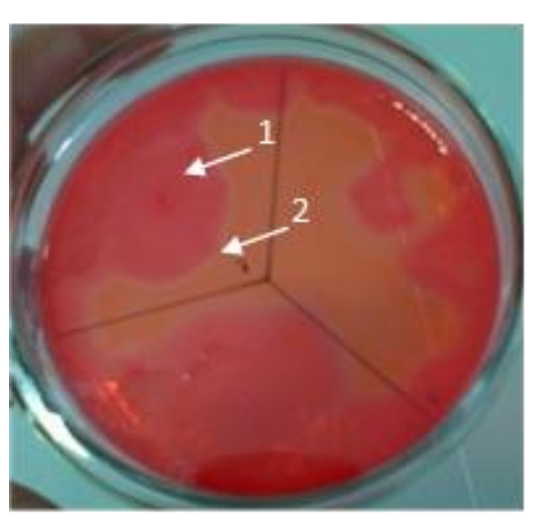

(a)

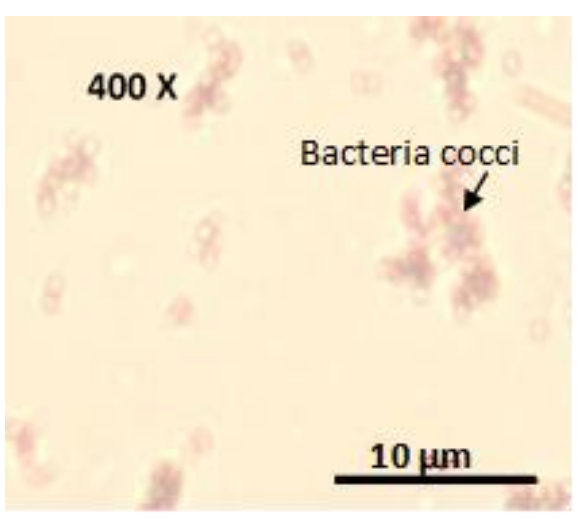

(b)

Figure 3. (a) Irregularly-shaped bacteria colony: 1 is the colony, 2 is the clear zone around the colony; (b) the morphology of the bacteria colony from 400x magnification microscope observation (isolation condition: $\mathrm{CCRA}, 25^{\circ} \mathrm{C}, 48$ hours) 


\subsection{Isolation and characterization of lignocellulolytic microbes}

The capability of microbes to facilitate the decomposition of lignocellulosic biomass is measured with cellulolytic, lignolytic, and lignocellulolytic indices. These indices are essentially diameter ratio of the microbes' colony and the clear zone around the respective colony. Thus, the clear zone test is only considered as a preliminary test. This test is particularly difficult due to the often irregularly shaped colony and clear zone around it.

The clear zone indicates the level of solubility of the enzyme. The higher the level of solubility of the enzyme, the greater the clear zone formed. The diameter of clear zone is generally larger than the diameter of the colonies because the enzyme is secreted into the surrounding environment (Zverlov et al., 2003).

\section{Cellulolytic activity}

Cellulolytic microbial selection using CCRA media defined 12 isolates, consist two bacterium and 10 fungi, to be investigated further for identification of their potential of cellulolytic activity. The selection was based on the morphology and cellulolytic index that have been characterized. The higher the cellulolytic index, the higher the capability to degrade the cellulose material (higher cellulolytic activity). The cellulolytic activities from the lowest to the highest are presented in Table 1.

Table 1. Cellulolytic index of microbes derived from EFB wastes

\begin{tabular}{lcccc}
\hline \multicolumn{1}{c}{ Location } & Isolate code & Colonies morphology & Cellulolytic index & $\begin{array}{c}\text { Types of } \\
\text { microbes }\end{array}$ \\
\hline Samuntai POM & B1-1 & yellow, mucus & 0.5 & Bacteria \\
Longkali POM & A3-1 & yellow, mucus & 0.25 & Bacteria \\
Longkali POM & A1-2 & white spore & 1.5 & Fungi \\
Longkali POM & A1-1 & white spore & 2 & Fungi \\
Longkali POM & A3-2 & white spore & 3 & Fungi \\
Longkali POM & A2-1 & white spore & 3.25 & Fungi \\
Samuntai POM & B3-2 & white spore & 4.7 & Fungi \\
Samuntai POM & B1-2* $^{*}$ & Red & 8.5 & Fungi \\
Samuntai POM & B2-1 $^{*}$ & Red & 10 & Fungi \\
Samuntai POM & B3-1 $^{*}$ & white spore & 10.7 & Fungi \\
Longkali POM & $\mathbf{A 2 - 2}$ & white spore & 14 & Fungi \\
Samuntai POM & B2-2 $^{*}$ & white spore & 14 & Fungi \\
\hline Five isolates with the best cellulolytic activity & & &
\end{tabular}

\section{Lignolytic activity}

Using LgA media, we were able to obtain 12 isolates that have lignin degradation capability, evidenced by the presence of clear zone around the colonies (Figure 4). The lignolytic activities, from the lowest to the highest, are presented in Table 2. Lignin is a noncarbohydrate fraction and the most difficult to degrade lignocellulosic component (Kuhad et al., 2007). Lignin is an aromatic phenolic polymer of coniferyl, sinapyl and $p$ coumaryl alcohol (Urairuj et al., 2003). It is three-dimensionally structured, branched, complex, and has a high molecular weight. Although the mechanism of decomposition of lignin has not been clearly known, many studies reported that fungi can degrade lignin to $\mathrm{CO}_{2}$ and $\mathrm{H}_{2} \mathrm{O}$ (Risna \& Suhirman, 2002). Isolates that degrade lignin can be used for 
lignocellulosic pretreatment process, to reduce lignin matter and change its chemical and physical structure so decomposition process occurs more efficient (Isroi et al., 2011).

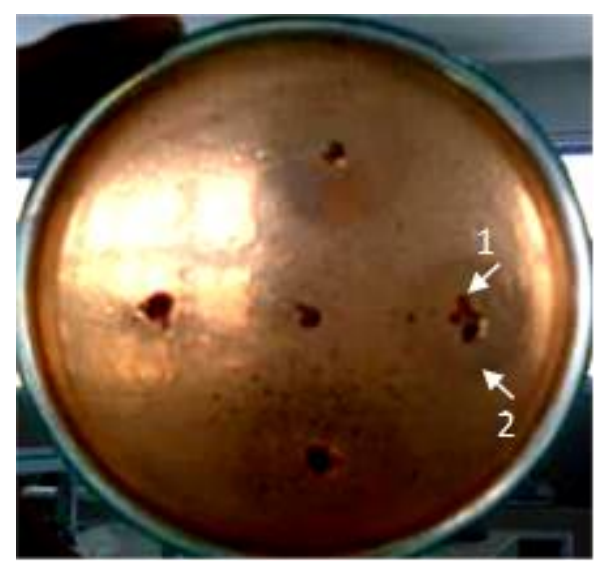

(a)

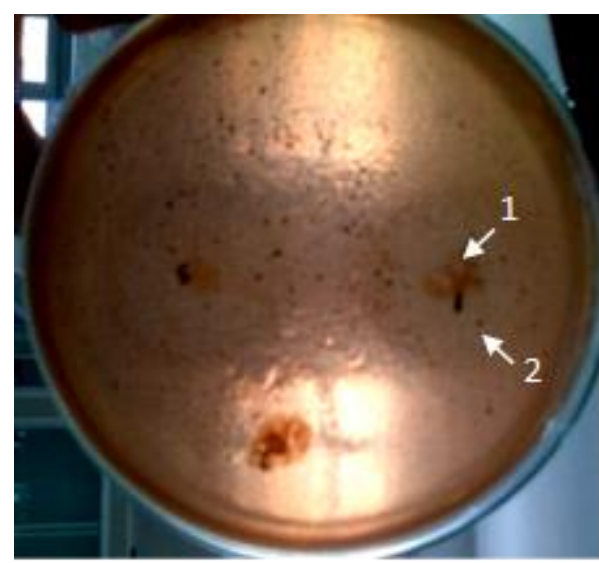

(b)

Figure 4. (a) The colonies of fungi: 1 is the colony, 2 is the clear zone around the fungi colony; (b) the colonies of bacteria: 1 is the colony, 2 is the clear zone around the bacteria colony (isolation condition: $\operatorname{LgA}$ media, $25^{\circ} \mathrm{C}, 48$ hours)

Table 2. The lignolytic activity of microbes derived from EFB wastes

\begin{tabular}{lccc}
\hline \multicolumn{1}{c}{ Location } & Isolate code & Lignolytic Index & Types of microbes \\
\hline Samuntai POM & B3-2 & 1 & Fungi \\
Longkali POM & A3-1 & 1 & Bacteria \\
Samuntai POM & B1-1 & 1.1 & Bacteria \\
Longkali POM & A1-2 & 1.7 & Fungi \\
Longkali POM & A1-1 & 2.4 & Fungi \\
Samuntai POM & B3-1 & 3 & Fungi \\
Longkali POM & A3-2 & 3 & Fungi \\
Samuntai POM & B2-2 $^{*}$ & 4 & Fungi \\
Longkali POM & $\mathbf{A 2 - 2}^{*}$ & 9 & Fungi \\
Samuntai POM & $\mathbf{B 2 - 1}^{*}$ & 21 & Fungi \\
Longkali POM & $\mathbf{A 2 - 1}^{*}$ & 16.5 & Fungi \\
Samuntai POM & $\mathbf{B 1 - 2}^{*}$ & 26.5 & Fungi \\
\hline
\end{tabular}

*Five isolates with the best lignolytic activity

\section{Lignocellulolytic activity}

The 12 isolates with highest lignocellulolytic activity are presented in Table 3 . These isolates were obtained using EFBCRA media, and the clear zones around the colonies were also distinctly observable as depicted in Figure 5. The size of the clear zone will be affected by the lignocellulolytic activity.

The presence of clear zone is an early suggestion that the isolates have capability as lignocellulosic biomass degrading microbes. These microbes are able to break down the complex of lignocellulosic biomass into monomers which can be used as the main carbon source for their metabolism. 
Based on enzyme biosynthesis ability, isolates A2-1, A2-2, B2-2, B2-1, and B1-2 were selected as the best isolates as it can synthesize cellulase and ligninase enzymes. These enzymes will accelerate the degradation of EFB substrate. Some studies demonstrated that adding cellulolytic microorganisms can accelerate the decomposition of organic matter. Therefore, employing indigenous lignocellulolytic microbes will accelerate the EFB decomposition process. Gusmawartati (1999) and Wahyuni (2008) reported that using one of cellulolytic microorganism or consortium of bacteria, fungi, or actinomycetes combined with the addition of chicken manure can rapidly diminish $\mathrm{C} / \mathrm{N}$ ratio during the decomposition of EFB.

Table 3. Lignocellulolytic activities of 12 isolate microbes

\begin{tabular}{lccc}
\hline Location & Isolate code & $\begin{array}{c}\text { Lignocellulolytic } \\
\text { Index }\end{array}$ & $\begin{array}{c}\text { Types of } \\
\text { microbe }\end{array}$ \\
\hline Samuntai POM & B1-1 & 0.2 & Bacteria \\
Longkali POM & A1-2 & 0.3 & Fungi \\
Longkali POM & A3-1 & 0.5 & Bacteria \\
Longkali POM & A1-1 & 0.6 & Fungi \\
Longkali POM & A3-2 & 1.5 & Fungi \\
Samuntai POM & B3-1 & 1.5 & Fungi \\
Samuntai POM & B3-2 & 2.7 & Fungi \\
Longkali POM & A2-1* & 4 & Fungi \\
Longkali POM & A2-2* & 4 & Fungi \\
Samuntai POM & B2-2 $^{*}$ & 4 & Fungi \\
Samuntai POM & B2-1 $^{*}$ & 7 & Fungi \\
Samuntai POM & B1-2 $^{*}$ & 7 & Fungi \\
\hline
\end{tabular}

* Five isolates with the best lignocellulolytic activity

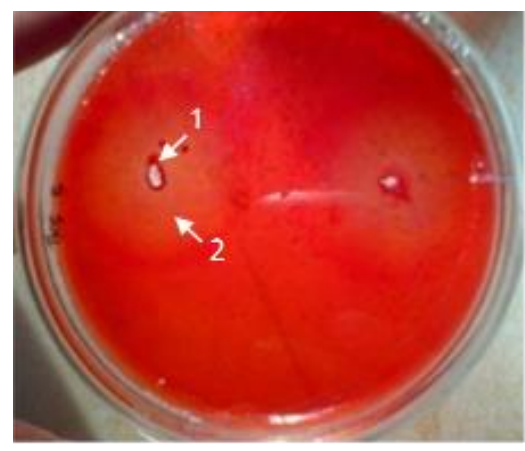

(a)

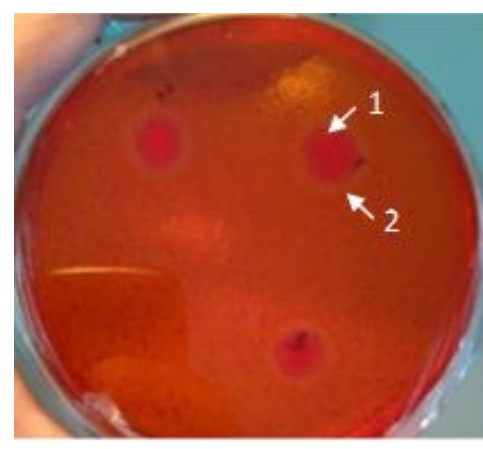

(b)

Figure 5. (a) The colonies of fungi: 1 is the colony, 2 is the clear zone around the fungi colony; (b) the colonies of bacteria: 1 is the colony, 2 is the clear zone around the bacteria colony (isolation condition: EFBCRA media, $25^{\circ} \mathrm{C}, 48$ hours)

\section{Conclusion}

This study has isolated 430 microbes from EFB wastes sampled from Longkali POM and samuntai POM, in East Kalimantan, Indonesia. After selected the best 12 isolates having the highest indices, five isolates of fungi (A2-1, A2-2, B2-2, B2-1, and B1-2) found to have the best lignocellulolytic activity. This result will be followed up with a more 
comprehensive study to produce data and information that can be used for an industrial base lignocellulosic wastes processing.

\section{Reference}

Andayani, R. (2011). Pembuatan Bioetanol dari Tandon Kosong Kelapa Sawit Melalui Proses Fungal Treatment oleh Aspergillus niger dan Fermentasi oleh Zygomonas mobilis. Institut Teknologi Sepuluh Nopember.

Atlas, R. M., \& Bartha, R. (1986). Microbial ecology: fundamentals and applications. Menlo Park: Benjamin-Cummings Pub. Co.

Azizah, S. N., Muzakhar, K., \& Arimurti, S. (2014). Screening of Cellulolytic bacteria from Vermicomposting Empty Fruit Bunch of Palm Oil. Berkala Sainstek, 2(1), 26-30.

Baharuddin, A. S., Kazunori, N., Abd-Aziz, S., Tabatabaei, M., Abdul Rahman, N. A., Hassan, M. A., ... Shirai, Y. (2009). Characteristics and Microbial Succession in Co-Composting of Oil Palm Empty Fruit Bunch and Partially Treated Palm Oil Mill Effluent. The Open Biotechnology Journal, 3(1), 87-95. http://doi.org/10.2174/1874070700903010087

Goenadi, H. D., \& Away, Y. (1993). Seleksi dan Isolasi Fungi Pelapuk Putih dari TKKS. Menara Perkebunan, 63, 88-101.

Gunam, I. bagus W., Buda, K., \& Guna, I. M. Y. S. (2010). Pengaruh perlakuan delignifikasi dengan $\mathrm{NaOH}$ dan konsentrasi substrat jerami padi terhadap produksi enzim selulase dari aspergillus niger NRRL-AII, 264. Jurnal Biologi, 14(2), 55-61.

Gusmawartati. (1999). Pengaruh Pemberian Mikroorganisme Selulolitik dan Kotoran Ayam Terhadap Dekomposisi Tandan Kosong Kelapa Sawit. Universitas Sumatera Utara.

Hatakka, A. (2005). Biodegradation of lignin. In Biopolimers Online.

Isroi, Millati, R., Syamsiah, S., Niklasson, C., Cahyanto, M. N., Lundquist, K., \& Taherzadeh, M. J. (2011). Biological pretreatment of lignocelluloses with white-rot fungi and its applications: A review. BioResources, 6(4), 5224-5259. http://doi.org/10.15376/biores.6.4.5224-5259

Kausar, H., Sariah, M., Ismail, M. R., Saud, H. M., \& Habib, S. H. (2012). Development of a potential lignocellulolytic resource for rapid bioconversion of rice straw. African Journal of Biotechnology, 11(38), 9235-9242. http://doi.org/10.5897/AJB10.212

Kuhad, R. C., Kuhar, S., Kapoor, M., Sharma, K. K., \& Singh, A. (2007). Lignocellulolytic microorganisms, their enzymes and possible biotechnologies based on lignocellulolytic microorganisms and their enzymes. In R. C. Kuhad \& A. Singh (Eds.), Lignocellulose Biotechnology: Future Prospects. New Delhi: IK International Pvt Ltd, 322.

Kumar, P., Barret, D. M., Delwiche, M. J., \& Stroeve, P. (2009). Methods for pretreatment of lignocellulosic biomass for efficient hydrolysis and biofuel production. Industrial and Engineering Chemistry Research, 48(8), 3713-3729.

Kurakake, M., Ide, N., \& Komaki, T. (2007). Biological pretreatment with two bacterial strains for enzymatic hydrolysis of office paper. Current Microbiology, 54(6), 424428. http://doi.org/10.1007/s00284-006-0568-6 
Meryandini, A., Widosari, W., Maranatha, B., Sunarti, T. C., Rachmania, N., \& Satria, H. (2009). Isolasi bakteri selulolitik dan karakterisasi enzimnya. Makara Sains, 13(1), 33-38. http://doi.org/10.7454/mss.v13i1.369

Mukhlis, Mohd Saud, H., Sariah, M., Razi Ismail, M., Habib, S. H., \& Kausar, H. (2013). Potential lignocellulolytic Trichoderma for bioconversion of oil palm empty fruit bunches. Australian Journal of Crop Science, 7(3), 425-431.

Oktavia, B. (2010). Kajian Kekayaan Bakteri Indigenous Indonesia untuk Boremidiasi Limbah. Yogyakarta: Jurusan Pendidikan Biologi, Universitas Negeri Yokyakarta.

Pérez, J., Muñoz-Dorado, J., De La Rubia, T., \& Martínez, J. (2002). Biodegradation and biological treatments of cellulose, hemicellulose and lignin: An overview. International Microbiology, 5(2), 53-63. http://doi.org/10.1007/s10123-002-0062-3

Prihandana, R., \& Hendroko, R. (2008). Energi Hijau: Pilihan Bijak Menuju Negeri Mandiri Energi. Jakarta: Penebar Swadaya.

Risna, R. A., \& Suhirman. (2002). Ligninolytic enzyme production by Polyporaceae from Lombok, Indonesia. Fungal Diversity, 9, 123-134.

Suriadikarta, D. A., Simanungkalit, R. D. M., Saraswati, R., Setyorini, D., \& Hartatik, W. (2006). Pupuk Organik dan Pupuk Hayati. Bogor: Balai Besar Litbang Sumber Daya Lahan Pertanian.

Taherzadeh, M. J., \& Karimi, K. (2007). Enzyme-based hydrolysis processes for ethanol from lignocellulosic materials: A review. BioResources, 2(4), 707-738. http://doi.org/10.15376/BIORES.2.3.472-499

Tristianti, S. Y., Sarjono, P. R., \& Mulyani, N. S. (2013). Aktivitas Fusarium oxyporum dalam menghidrolisis enceng gondok (eichhornia crassipes) dengan variasi waktu fermentasi. Chem Info, 1(1), 265-273.

Urairuj, C., Khanongnuch, C., \& Lumyong, S. (2003). Ligninolytic enzymes from tropical endophytic Xylariaceae. Fungal Diversity, 13(June 2015), 209-219. Retrieved from http://www.scopus.com/scopus/inward/record.url?eid=2-s2.02342445666\&partnerID=40\&rel=R7.0.0

Wahyuni, M. (2008). Laju Dekomposisi Aerob dan Mutu Kompos Tandan Kosong Kelapa Sawit dengan Penambahan Mikroorganisme Selulolitik, Amandemen dan Limbah Cair Pabrik Kelapa Sawit. Universitas Sumatera Utara.

Zverlov, V. V., Höll, W., \& Schwarz, W. H. (2003). Enzymes for digestion of cellulose and other polysaccharides in the gut of longhorn beetle larvae, Rhagium inquisitor $\mathrm{L}$. (Col., Cerambycidae). International Biodeterioration and Biodegradation, 51(3), 175179. http://doi.org/10.1016/S0964-8305(02)00139-7 